\title{
An Analysis of Illocutionary Acts Produced by the Lecturer in Online Classroom Interaction
}

\author{
Dessy Karmila Sari ${ }^{1 *}$, Noor Eka Chandra ${ }^{2}$, Yusuf Al-Arief ${ }^{3}$ \\ ${ }^{1,2,3}$ Lambung Mangkurat University \\ "Corresponding author. Email: 1710117220007@mhs.Ulm.ac.id
}

\begin{abstract}
This study aimed to figure out the types of illocutionary acts produced by a lecturer in online classroom interaction and the functions of the illocutionary acts. This research applied a descriptive qualitative design by involving a lecturer of the English Language Department of Lambung Mangkurat University. The data was collected by using an observation sheet, interview guide, and recording which was analyzed following the steps namely data reduction and data display. The result showed that the lecturer produced four kinds of illocutionary acts in online classroom interaction. There were 275 utterances of illocutionary acts conveyed by the lecturer during the teaching and learning comprising of 165 directive data, 86 expressive data, 23 representative data, and 1 commissive data. Moreover, the findings showed that there were three kinds of illocutionary functions based on 250 data collected. They are 161 competitive data, 86 convivial data, and 3 collaborative data. The lecturer also used questions in the teaching and learning process to engage students in the discussion and assist the lecturer in assessing the students' knowledge on the lesson materials. This finding implies that further research is needed by expanding the focus of speech acts to obtain more comprehensive data about speech acts in online classroom interaction.
\end{abstract}

Keywords: Speech acts, Illocutionary acts, Classroom interaction.

\section{INTRODUCTION}

Interaction can occur anywhere, including in a classroom. In a classroom, the lecturer will share the knowledge and information to the students through oral language. Both the lecturer and the students will produce utterances. In the learning process, the goal will be reached if the interaction between the teacher (lecturer) and the students is good. When an interaction occurs, a learning process also occurs. Every utterance produced by the lecturer has certain meanings and functions. Thus, speech acts have communicative force behind the performance of an utterance [13]. Therefore, everything that the lecturer conveyed to the students will have an effect on the students, and what the students obtain will influence the learning process. Considering how important the role of interaction is in a classroom, the researchers investigated the utterance produced by the lecturer when they have interaction in a classroom by using a pragmatic approach. Pragmatics focused on understanding what is the true meaning that the speaker tried to convey to the listener because sometimes there is something unsaid but it is part of communication. Hence, to investigate the language needs the tools of pragmatics, evolved by the different theorists, speech acts.

According to Searle [9] speech acts performed in one's utterance has the function as it gives meaning. When a speaker delivers the utterance, it may mean more than what is said because not all of the meaning of utterance determines what speech acts are performed in giving utterance. In classroom interaction, several kinds of speech acts are used in all verbal utterances. There are three types of acts and one of them is the illocutionary act. Illocutionary is an utterance but there is an act embedded in it. It takes important roles in communication because it becomes the basis in an analysis of comprehension in pragmatics.

Moreover, Searle [9] divided speech acts into three kinds namely locutionary acts, illocutionary acts, and perlocutionary acts. The illocutionary act can be defined as an act of doing something with an embedded certain purpose and function. When the speaker says hungry, the speaker does not merely inform the listener that he is in a state of hunger, but the speaker intended for the 
listener to do certain actions along with his hunger, for example giving some foods.

Interaction plays an important role in improving students' ability in communication. This happens because the more interactions occur, the more communication is. Hence, the use of speech acts cannot be avoided during the interaction in the classroom. It also makes the researchers interested to figure out the types and functions of every utterance produced by the lecturer, especially interaction in the online classroom.

\section{LITERATURE REVIEW}

Some theories are utilized in this research to support the study as follows:

\subsection{Classroom Interaction}

The interaction between the lecturer and students is a part of the process of teaching. The efficiency of the interaction between the lecture and students or between the students and students will determine the success or failure of the teaching $[3,12]$. Furthermore, how the lecturer interacts and uses the suitable language in the learning process is the important thing in reaching the purpose of teaching. In other words, when the interaction of the classroom occurs, the lecturer will produce utterances and they intend some purpose and function. Hence, teachers used speech acts with various types and functions to engage students in the classroom interaction (Basra \& Thoyyibah, 2017) including in EFL classrooms in which interactions barely occur due to the challenge in making students understand teachers' utterances and instructions (Santosa \& Kurniadi, 2020).

According to Dian (2015), there are three types of interaction occurs in a teaching and learning process. They are teacher-students interaction, students-teacher interaction, and students-students interaction

\subsection{Online Learning}

Since Covid-19 has outbreak over the world it influences the entire sector and one of them is in the education sector. In this situation, all of the learning processes take place online. Online learning is the learning which involves technologies as well as email, chat, web, or audio-video conference. According to Efriana (2021) in the process of learning, both lecturer or the students face some challenges, that is, students' understanding of the subject material. The next challenges are lack of teachers' explanation when using technology in online learning and the difficulties in controlling the learning. Teachers need to find the solutions to make the learning process run well. For example, before the lesson the teacher should prepare the learning material and give the students before the class to give them enough time to read. Then, regarding the limitation on mastery of technology, the teacher should learn about how to use technology in teaching.

\subsection{Speech Acts}

According to Searle [9] speech acts are the acts performed by utterance which has the function or meaning of the sentence. Searle divided speech acts into three in practice the use of language. The three kinds of speech acts are locutionary acts, illocutionary acts, and perlocutionary acts. Furthermore, Searle [9] divided illocutionary acts into five types. The first is representative that is an act where the speaker is doing something to bring the case to the truth of the expressed proposition such as stating, boasting, suggesting, claiming, explaining, insisting, reporting, suggesting, and swearing. The second is directives; an act that is used by the speaker to get the listener to do something. It consists of requesting, ordering, commanding, recommending, and advising. The third is expressive which means an act that happens when the speaker expresses their feelings when they speak. It is a psychology related act of the speaker to express his attitude towards a state. The acts are congratulating, thanking, praising, condoling, pardoning, and blaming. The fourth is commissive that is used by the speaker to commit themselves to do certain action in the future. These consists of vowing, offering, and promising. The last is declarative; a kind of speech act that can change the world by the speaker's utterance. The acts are sentencing, appointing, christening, resigning, naming, and dismissing.

According to Leech [7], there are four types of speech acts based on the functions that is related to social goals and maintaining politeness. The first is competitive with the function for competing. The second is convivial which functions for compliance. The third is collaborative which is aimed for ignoring. Finally is conflictive which functions for conflicting against the social purposes.

\subsection{Context}

According to Leech [7], context is something that the speaker and listener should have. Context is the background of knowledge that contributes to the interpretation of the listener in what the speaker means by the given utterance produced. Moreover, Nunan [6] defines context as the situation which raises the discourse where the discourse is embedded. When the speaker produced an utterance, it will have a different meaning when having the different context 


\section{RESEARCH METHOD}

This researcher applied a descriptive qualitative design since it was intended to identify the types and functions of the illocutionary act made by the lecturer in online classroom interaction. Moreover, descriptive qualitative is used to analyze the data. The subject of this research was an English language lecturer at Lambung Mangkurat University. The subject was chosen based on the highly frequent use of English language during teaching. This research used only utterances produced by the lecturer during the online learning process. To collect the data, several methods were implemented namely observation, recording, transcription, and interview. Then, the data was analyzed through three steps consisting of reducing the data, displaying it, drawing conclusion, and verifying the data. The data was reduced by eliminating irrelevant data. Then, the data was classified and displayed based on the category of illocutionary acts. Finally, the data was interpreted in order to come a comprehensive conclusion.

\section{RESULTS AND DISCUSSION}

This research was arranged during the pandemic Covid-19, thus all of the learning and teaching processes were conducted online. The length of the learning process was also limited into an hour in every meeting. This research was conducted to find the types and the function of the illocutionary act produced by the lecturer in online classroom interaction. The researcher chose a lecturer from the English Education Department of ULM Banjarmasin. The researcher classified the data based on Searle's classification. The findings can be seen in Table 1.

Table 1. Types of Illocutionary Acts Produced by the Lecturer in Online Classroom Interaction

\begin{tabular}{|c|c|c|}
\hline Activity & $\begin{array}{c}\text { Types of } \\
\text { Illocutionary Acts }\end{array}$ & Frequency \\
\hline Opening & Expressive & 6 \\
\cline { 2 - 3 } & Directive & 11 \\
\cline { 2 - 3 } & Representative & 4 \\
\hline \multirow{4}{*}{ While } & Directive & 140 \\
\cline { 2 - 3 } & Expressive & 78 \\
\cline { 2 - 3 } & Representative & 15 \\
\cline { 2 - 3 } & Commissives & 1 \\
\hline Closing & Directive & 11 \\
\cline { 2 - 3 } & Expressive & 5 \\
\cline { 2 - 3 } & Representative & 4 \\
\hline & TOTAL & $\mathbf{2 7 5}$ \\
\hline
\end{tabular}

As seen in Table 1, the lecturer produced four types of illocutionary acts. There were 165 directive data, 86 expressive data, 23 representative data, and 1 commissive data. Totally, there were 275 utterances produced by the lecturer during online classroom interaction. In online learning, the lecturer did not produce the declarative type.

The next is the functions of illocutionay acts produced by the lecturer. The summary is displayed in Table 2.

Table 2. The Function of Illocutionary Acts Produces by the Lecturer in Online Classroom Interaction

\begin{tabular}{|c|c|c|}
\hline Activity & $\begin{array}{c}\text { The Illocutionary Acts } \\
\text { Function }\end{array}$ & Frequency \\
\hline \multirow{3}{*}{ Opening } & Competitive & 14 \\
\cline { 2 - 3 } & Convivial & 5 \\
\hline \multirow{3}{*}{ While } & Competitive & 138 \\
\cline { 2 - 3 } & Convivial & 79 \\
\cline { 2 - 3 } & Collaborative & 2 \\
\hline \multirow{2}{*}{ Closing } & Competitive & 11 \\
\cline { 2 - 3 } & Convivial & 5 \\
\hline & TOTAL & $\mathbf{2 5 4}$ \\
\hline
\end{tabular}

As displayed in Table 2, the lecturer produced three functions of illocutionary acts. In the pre activity, the lecturer produced a competitive and convivial function. In the while activity, the lecturer performed competitive, convivial, and collaborative. Finally, in the post activity, the lecturer performed competitive and convivial function.

Based on three times observation, the researchers found four types of illocutionary acts conveyed by the lecturer, they are directive, expressive, representative, and commissive. In the opening of the activity, the lecturer used various types of illocutionary acts such as expressive, directive, and representative. The expressive type was performed by the lecturer in greeting the students at the beginning of the lesson. The greeting was to build the atmosphere of learning and get the students' attention. Furthermore, the directive types of illocutionary acts is the most dominant type used by the lecturer. When the lecturer performed directive questioning, it allowed the students to be more active in the classroom. It also helped the lecturer to check the students' understanding of the lesson. This is in line with Chai [3] stating that speech acts that are efficiently used and understood will increase the quality of teacher and students interaction.

Different from the opening activity, in the while activity the types of illocutionary acts used by the lecturer was expressive to give an appreciation to the students who have done something. The expression of praise is also performed by the lecturer such as "very good, good job, and good". These expressions made the 
students feel appreciated by the lecturer. In the while activity, the lecturer also used the representative of explaining because in the online learning, the material is already distributed to the students before class in a form of video or PowerPoint (PPT) slides. Therefore, when the lecturer and the students have the synchronous meeting, they will discuss the lessons only to enhance the students' comprehension.

In the closing activity, the lecturer used directive, expressive, and representative types of illocutionary acts. In this activity, the directive type of questioning was used by the lecturer in the evaluation section. This was aiemd to confirm whether the students understood the material of the study or not. Moreover, in the postactivity, the lecturer gave an evaluation, homework, or assignment and the representative of explaining was used by the lecturer in this section to clarify things pertaining to the assignment and the instruction.

The results showed that in online classroom interaction, the lecturer performed four types of illocutionary acts namely directive, expressive, representative, and commissive. These findings are similar to those found by Sukinah and Efendi [11] except that in their study, the lecturers employed assertive, directive, expressive, and commissive. Furthermore, directive was the mostly used type during the interaction. This finding is in line with the finding of a study by Armistany and Zamzani [1] and Christianto [4] showing that directive was the type that was mostly used by teacher. The current study also showed that commissive is the least used type of illocutionary acts. It is in line with the finding of a study by Santosa and Kurniadi [8] revealing that commissive is the least used act in the teaching and learning interactions.

During the teaching and learning process, the lecturer conveyed the types of illocutionary functions in 250 utterances. In all of the activities from the opening to the post activity, the lecturer mostly used the competitive types of illocutionary function. It is because this types of illocutionary function can be applied in online classroom interaction to manage and control the activities of the students. The purpose of the use of competition is to make the students more participate during the teaching and learning process. Similarly, a study by Basra and Thoyyibah [2] also found that the teacher used this type of illocutionary act to make students engage in the interaction. Meanwhile, competitive asking is mostly performed by the lecturer to check the students' comprehension of the teaching material.

In the while activity, the illocutionary acts of conviviality functions was the most dominantly performed by the lecturer during the online classroom interaction. Convivial functions aimed for compliance with the social purposes, for example, the expression of thanking, praising, etc. The expression of praise was used by the lecturer to give an appreciation to students when they have finished doing something, for example after they answered the lecturer's questions.

The last types were competitive and convivial that were found in closing activity. The function of competition as the most important function used by the lecturer is along with the previous activity that the competition of questioning used by the lecturer to activate the students. Meanwhile, the lecturer performed conviviality through the expressions of praising and thanking to encourage the students in the learning and enhance the relationship between the lecturer and students. Therefore, the lecturer produced three functions of illocutionary acts which comprised of competitive, convivial, and collaborative. Competitive is the most dominantly used by the lecturer followed by the convivial. The collaboration of statements used by the lecturer to deliver the information related to the material they have.

\section{CONCLUSION}

Based on the data analysis, the lecturer performed four types of illocutionary acts during online teaching and learning. They were directive, expressive, representative, and commissive with the directive as the types of illocutionary act mostly used by the lecturer. Furthermore, it was found that three functions of illocutionary acts conveyed in the online classroom were competitive as the most dominantly used followed by the convivial and collaborative.

This study has some implications. For the lecturer, this study brings insight about interaction during the online teaching and learning, especially on the types and functions of illocutionary acts. The insight can improve the nature of interaction during online learning. This study also implies that further research is needed to investigate illocutionary acts in online classroom by expanding the types of acts to obtain more comprehensive findings.

\section{AUTHORS' CONTRIBUTIONS}

Author 1 is responsible for research designs, data analysis, and paper writing. Author 2 is responsible for the research design and proofreading whereas Author 3 is responsible for the format of writing.

\section{ACKNOWLEDGMENTS}

The researchers would like to address their highest gratitude to the research subject for being very cooperative in the study.

\section{REFERENCES}

[1] P. Armistany, Z. Zamzani, The Functions of Illocutionary Speech Acts used by Teachers in the Classroom Interaction, in: Proceedings of LINGUA. vol. 14, issue 1. 2019, pp187-196. 
[2] S. M. Basra, L Thoyyibah, A speech act analysis of teacher talk in an EFL classroom, in : Proceedings of International Journal of Education, vol. 10, issue 1, 2017, $\quad$ pp. $73 \quad-81$. DOI:http://dx.doi.org/10.17509/ije.v10i1.6848

[3] K. Chai, The Principles and The Ways of Classroom Interactions: school of foreign languages, Jiujiang University, 2015.

[4] D. Christianto, Speech Acts in EFL Classrooms in: Proceedings of Journal of Pragmatics Research, vol.2, no. 1, 2020, pp 68-79. DOI: https//doi.org/10.1836/jopr.v2i1.1-68-79

[5] D. Kusumasuci, Classroom Interactions In Speaking Class of English Department of Muhammadiyah University of Surakarta, Program of Language Study of Muhammadiyah University of Surakarta, 2015.

[6] D. Nunan, Introduction Discourse Analysis. London, Penguin English, 1993.

[7] N. Leech, Principles of Pragmatics, London: Longman. H 250pp, 1983.

[8] W.A. Santosa, A. Kurniadi, Speech Acts Analysis of Teacher Talk in EFL Classroom, in: Proceedings of Jurnal Penelitian Humaniora, vol. 21 no.2, 2020, pp. 101-107. DOI. https://doi.org/10.23917/humaniora.v20i2.9871

[9] J. R. Searle, Speech Acts, An Essay in the Philosophy of Language, Cambridge University Press, United Kingdom, 1969.

[10] J. R. Searle, Introduction to the Theory of Speech Acts, Cambridge University Press, 1983.

[11] S. Sukinah, A. Efendi, Teacher's Illocutionary Acts in Online Learning Interactions. Jurnal Pendidikan dan Pengajaran, vol.54, no 1. 2021. pp 28-37. DOI:http://dx.doi.org'10.23887/jpp.v54i1

[12] K. D. Wibowo, A Pragmatic Analysis of Illocutionary Acts in English Teaching-Learning Process at SMA N 1 Wates Kulon Progo, Yogyakarta, English Education Study Program English Education Department Faculty of Languages and Arts Yogyakarta State University, 2015.

[13] G. Yule, Pragmatics, New York, Oxford University Press, 1996. 